\title{
PRESTASI BELAJAR SISWA DALAM DIKLAT LESSON STUDY
}

\author{
I P. O. Indrawan \\ Program Studi Manajemen Informatika, \\ Politeknik Ganesha Guru, Indonesia \\ E-mail: oktap8indrawan.bali@gmail.com
}

\begin{abstract}
Abstrak
Tujuan penelitian ini adalah untuk: (1) Mendeskripsikan kualitas pelaksanaan diklat lesson study pada guru IPA di SMK Negeri 2 Seririt; dan (2) Menganalisis perbedaan prestasi belajar IPA siswa sebelum dan sesudah diklat lesson study. Jenis penelitian ini adalah pre-experimental dengan desain penelitian one group pretest-postest design. Pengambilan sampel siswa untuk penelitian digunakan teknik random sampling. Data kualitas diklat lesson study dianalisis secara deskriptif kualitatif. Sedangkan, prestasi belajar siswa dianalisis dengan analisis tatistik deskriptif dan inferensia, di mana uji hipotesis penelitian data prestasi belajar siswa menggunakan paired sample test. Hasil penelitian menunjukkan: (1) Kualitas pelaksanaan diklat lesson study tergolong kualifikasi sangat baik $(\bar{X}=91,781)$; dan (2) terdapat perbedaan yang signifikan prestasi belajar IPA siswa sebelum dan sesudah diklat lesson study $(t=123,8493 ; p<0,05)$.
\end{abstract}

Kata kunci: diklat lesson study, dan prestasi belajar

\begin{abstract}
The aims of this study were: (1) to describe the quality of the workshop of lesson study on science teachers at SMKN 2 Seririt; and (2) to analyze the differences of the student's learning achievement in science subject before and after workshop of lesson study at SMKN 2 Seririt. This study was a pre-experimental study using one group pretest-postest design. The population of this study were focused on eleventh grade students of SMKN 2 Seririt in the academic year 2013/2014. The samples of the class for this study was determined by random sampling technique. The data were analyzed by descriptive statistics and hipotesis analyzed by paired sample t-test for the data of student's achievement in science subject. The result showed that: (1) the workshop of lesson study on science teachers at SMKN 2 Seririt fell into very good qualification $(\bar{X}=91,781)$; and (2) there were significant differences of the student's learning achievement in science subject before and after workshop of lesson study $(t=123,8493 ; p<0,05)$.
\end{abstract}

Keywords: workshop of lesson study, and learningachievement

\section{PENDAHULUAN}

Pendidikan merupakan investasi sumber daya manusia (SDM) jangka panjang yang mempunyai nilai strategis bagi kelangsungan kehidupan manusia di dunia. Sehingga semua negara di dunia menempatkan pendidikan sebagai sesuatu yang penting dan utama yang akan digunakan untuk pembangunan bangsa dan negara. Indonesia juga menempatkan pendidikan sebagai suatu hal yang penting dan utama dan harus selalu diperhatikan (Febrina, 2012). Permasalahan pendidikan yang dihadapi saat ini adalah rendahnya mutu pendidikan khususnya pada jenjang pendidikan dasar dan menengah. Untuk meningkatkan kualitas pendidikan harus dilakukan dari peningkatan kualitas guru, tapi pada kenyataannya bahwa kualitas guru di Indonesia masih tergolong rendah. Kinerja kualitas guru dapat dilihat daritingkat pendidikan 
kepala sekolah dan guru. Semakin tinggi pendidikannya tentu saja kualitasnya semakin bagus. Tingkat pendidikan dari kepala sekolah dan pengajar juga sekaligus mencerminkan tingkat kelayakan guru (Bustami, 2009).

Kompetensi professional guru khusus SMK Mata Pelajaran IPA di daerah provinsi Bali untuk SMK Buleleng memperoleh nilai minimal 41,07; maksimal 50,00; dan rerata 46,07 . Nilai tersebut tercatat paling rendah reratanya dibandingkan Denpasar $(48,66)$, Badung $(58,93)$, dan Bangli $(55,36)$. Menurut Renes (2009) beberapa faktor yang merupakan kendala ketidaklulusan uji kompetensi guru antara lain disebabkan oleh: (1) Minimnya bukti fisik pada pendidikan dan pelatihan; (2) Pengalaman mengajar yang digunakan sesuai dengan SKnya sebagai PNS atau guru Bantu; (3) Semua telah membuat perencanaan pembelajaran tetapi belum maksimal karena masih kesulitan untuk mendapatkan materi yang baru dan relevan; (4) Penilaian dari atasan dan pengawas sebagian besar merasakan baik, ada juga yang merasakan cukup; (5) Sebagian besar belum pernah membuat karya pengembangan profesi; (6) Sebagian besar pernah mengikuti forum ilmiah tetapi hanya sebagai peserta; dan (7) Penghargaan yang relevan dengan bidang pendidikan yang dimiliki juga sangat minim.

Rendahnya kompetensi guru merupakan salah satu penyebab rendahnya prestasi belajar siswa hal ini terbukti khususnya dari nilai rata-rata kognitif siswa kelas X SMKN 2 Seririt masih kecil dilihat dari nilai akhir semester dua tahun terakhir yaitu tahun 2012 dan 2013 secara berurut sebelum diangkat sesuai KKM adalah 61,382 dan 67,484 . Hal ini juga terjadi di beberapa sekolah misalnya di: (1) SMK Ksatrian Solo Sidoarjo 2010/2011 nilai rata-rata 73,07 masih di bawah KKM yaitu 75 (Astuti, 2012); dan (2) kondisi pembelajaran kelas X Program Keahlian Tata Busana 2 SMK Negeri 4 Surakarta tahun ajar 2012/2013 rata-rata nilai di bawah KKM yaitu 63,36 (Masitoh, 2013).

Berbagai usaha pemerintah misalnya melalui penataran dan pelatihan belum memberikan dampak yang signifikan terhadap peningkatan mutu guru. Hal tersebut disebabkan oleh dua hal pokok, yaitu: 1) penataran dan pelatihan yang dilakukan tidak pada permasalahan yang nyata di kelas; dan 2) Hasil penataran dan pelatihan hanya menjadi pengetahuan saja, tidak diterapkan secara berkelanjutan di dalam kelas, di mana setelah kembali mengajar di kelas guru kembali mengajar dengan pola atau strategi sebelumnya (Susilo, 2011).

Susilo (2013) juga menyatakan upaya mengatasi kelemahan model penataran, pendidikan dan/atau pelatihan konvensional yang kurang memberi tekanan pada pasca pelatihan, maka perlu dirancang dan dikembangkan suatu model diklat lesson study sebagai salah satu pendekatan yang dipandang efektif untuk meningkatkan profesionalisme guru IPA.

Diklat Lesson Study adalah pendidikan dan latihan, di mana lesson study dimasukkan sebagai konten dan konteks dalam pelaksanaannya (Susilo, 2013). Lesson study sendiri merupakan suatu model pembinaan profesi pendidik melalui pengkajian pembelajaran kolaboratif dan berkelanjutan berlandaskan prinsip-prinsip kolegalitas dan mutual learning untuk membangun komunitas belajar (Hendayana, dkk., 2006). Lesson study bukan merupakan suatu metode atau strategi pebelajaran tetapi kegiatan lesson study dapat menerapkan berbagai metode atau strategi pembelajaran yang sesuai dengan situasi, kondisi, dan permasalahan yang dihadapi guru.

Kelebihan diklat lesson study yaitu guru dapat: 1) Memformulasikan tujuan pembelajaran dan pengembangan jangka panjang; 2) Secara kolaboratif merancang suatu research lesson; 3) Melaksanakan pembelajaran dengan menugaskan seorang guru untuk mengajar dan anggota tim yang lain melakukan 
observasi untuk mengumpulkan data tentang kejadian belajar di kelas; 4) Mendiskusikan kejadian-kejadian belajar yang telah diobservasi selama proses pembelajaran, menggunakan informasi itu untuk memperbaiki kualitas pembelajaran; dan 5) Mengimplementasikan program pembelajaran yang telah direvisi pada kelas lain, dan jika perlu mengkaji dan memperbaiki kembali program pembelajaran tersebut (Lewis dkk, 2006).

Ada beberapa alasan mengapa lesson study dipilih sebagai basis dalam pengembangan model diklat guru IPA untuk meningkatkan kompetensi dan profesionalisme guru adalah: 1) Adanya kecenderungan para guru tenggelam dalam rutinitas cara mengajar yang monoton dan sulit untuk berubah dari sebelumnya, guru tidak melakukan inovasi dan kreativitas dalam pembelajaran, walaupun tuntutan saat ini telah berbeda. 2) Berbagai cara meningkatkan mutu pembelajaran guru di SMA/MA/SMK telah dilakukan, seperti menugaskan guru untuk mengikuti berbagai pelatihan perorangan, sayangnya hasil pelatihan ini terkesan belum memberikan dampak bagi sekolah. 3) Pembelajaran secara kolaboratif seperti diklat lesson study merupakan cara yang tepat untuk mengantisipasi tuntutan kompetensi guru, apalagi pada beberapa mata pelajaran saat ini dilakukan secara terpadu, yang artinya seorang guru harus professional pada mata pelajaran yang menjadi bidangnya. Dengan peningkatan kompetensi guru diharapkan nilai prestasi belajar siswa dapat meningkat.

\section{METODE PENELITIAN}

Jenis penelitian ini adalah preexperimental dengan desain penelitian one group pretest-postest design (Sugiyono, 2013). Rancangan ini dapat digambarkan seperti Gambar 1.

Rancangan one group pretsetpostest design dipilih untuk tujuan mengetahui efektivitas atau pengaruh perlakuan terhadap variabel dependen (Sugiyono, 2013). Dalam penelitian ini satu kelompok subjek diberikan perlakuan diklat lesson study. Hal yang dinilai pada subjek ini adalah prestasi belajar untuk siswa. Penilaian prestasi belajar siswa dilakukan sebelum pelaksanaan diklat lesson study dilambangkan dengan $\mathrm{O}_{1}$ (Pre-test), dan penilaian setelah diklat lesson study dilambangkan dengan $\mathrm{O}_{2}$ (Post-test). Perbedaan hasil pengukuran yang timbul dianggap sebagai akibat dari diklat lesson study yang diterapkan.

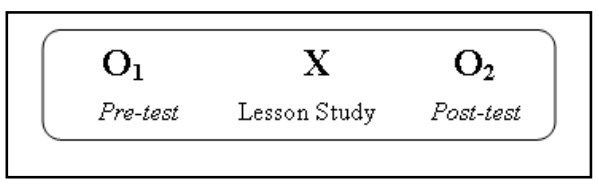

Gambar 1. Desain Penelitian One Group Pretest-Postest Design

Teknik pengambilan sampel yang digunakan dalam penelitian ini adalah random sampling yaitu teknik penentuan sampel dari populasi secara acak tanpa memperhatikan stratayang ada dalam populasi (Sugiyono, 2013). Populasi penelitian ini adalah seluruh siswa kelas $X$ pada tahun pelajaran 2013/2014 SMKN 2 Seririt berjumlah 172 orang dan sampelnya adalah siswa kelas $X$ Akuntansi 2 dan X MM 1 berjumlah 53 orang.

Dalam penelitian ini, data yang diambil ada dua yaitu: (1) kualitas pelaksanaan lesson study dan (2) prestasi belajar siswa. Data kualitas pelaksanaan diklat lesson study adalah respon positif observer yang diperoleh dari pengisian format monitoring meliputi aspek: plan (perencanaan), do (pelaksanaan), dan see (refleksi) yang kemudian kualifikasinya berdasarkan PAP. Pelaksanaan diklat lesson study bertujuan untuk meningkatkan kompetensi profesional guru. Tes kompetensi professional guru mengacu pada Pedoman Uji Kompetensi Guru Tahun 2012 (Kemendikbud, 2012a). Data prestasi belajar adalah skor prestasi belajar yang diperoleh dari tes prestasi belajar. Penilaian prestasi belajar siswa ditinjau dari ranah kognitif, digunakan tes dalam bentuk pilihan ganda (objektif) yang terdiri dari lima 
option (a, b, c, d, dan e) yang mengacu pada Taksonomi Bloom meliputi: pengetahuan, pemahaman, aplikasi, analisis, sintesis dan evaluasi (Wardani, 2004). SK "Memahami gejala-gejala alam melalui pengamatan" dan KD "Mengidentifikasi objek secara terencana dan sistematis untuk memperoleh informasi gejala alam abiotik" khusus materi gempa bumi dan tsunami.

Sebelum digunakan instrumen penelitian diujicobakan terlebih dahulu. Hasil uji coba tes prestasi belajar siswa adalah: validitas butir $(-0,125$ - 0,925), daya beda $(0,000-1,000)$, dan tingkat kesukaran butir tes $(0,200-0,833)$ maka terdapat 51 butir soal yang baik dan dari 53 butir soal.
Data kualitas diklat lesson study dianalisis secara deskriptif kualitatif. Sedangkan, prestasi belajar siswa dianalisis dengan analisis dengan statistik deskriptif dan inferensia, dimana data prestasi belajar siswa dianalisis menggunakan paired sample test (Sugiyono, 2012; Agusyana, 2011, dan Candiasa, 2010).

\section{HASIL DAN PEMBAHASAN}

Secara umum hasil penelitian dideskripsikan pada bagian ini, yaitu skor kualitas diklat lesson study dan skor prestasi belajar siswa sebelum dan sesudah mengikuti diklat lesson study. Pada Tabel 1 diperlihatkan data persentase guru yang memberikan respon positif teshadap lesson study.

Tabel 1.Persentase Observer yang Memberikan Respon Positif Terhadap Lesson Studi

\begin{tabular}{ccc}
\hline Tahap & $\begin{array}{c}\text { Persentase observer yang } \\
\text { memberikan respon positif }\end{array}$ & Kualifikasi \\
\hline Plan & 91,600 & Sangat baik \\
Do & 89,479 & baik \\
See & 94,263 & Sangat baik \\
Rerata & 91,781 & Sangat baik \\
\hline
\end{tabular}

Berdasarkan Tabel 1 dapat dideskripsikan persentase rata-rata observer yang memberikan respon postif terhadap lesson study adalah 91,781. Artinya, kualitas pelaksanaan diklat lesson study di SMK Negeri 2 Seririt tergolong sangat baik. Selanjutnya pada Tabel 2 ditunjukkan deskripsi nilai prestasi belajar siswa.

Tabel 2. Deskripsi Nilai Prestasi Belajar Siswa

\begin{tabular}{lccc}
\hline \multicolumn{1}{c}{ Statistik } & $\begin{array}{c}\text { Skor PBI Sebelum } \\
\text { Diklat LS }\end{array}$ & $\begin{array}{c}\text { Skor PBI Sesudah } \\
\text { Diklat LS }\end{array}$ & $\begin{array}{c}\text { Skor Gain } \\
\text { Ternormalisasi }\end{array}$ \\
\hline Rata-rata & 21,148 & 80,593 & 0,767 \\
Median & 20,000 & 82,000 & 0,775 \\
Modus & 20,000 & 80,000 & 0,838 \\
Standar Deviasi & 10,121 & 10,715 & 0,106 \\
Varian & 102,430 & 114,812 & 0,011 \\
Rentangan & 46,000 & 42,000 & 0,413 \\
Minimum & 2,000 & 54,000 & 0,531 \\
Maksimum & 48,000 & 96,000 & 0,944 \\
Jumlah & 1142,000 & 4352,000 & 41,391 \\
\hline
\end{tabular}

Berdasarkan Tabel 2 dapat dideskripsikan rata-rata skor gain ternormalisasi prestasi belajar siswa adalah 0,767. Artinya, efektivitas pelaksanaan diklat lesson study terhadap prestasi belajar siswa di SMKN 
2 Seririt masuk kualifikasi tinggi. Berdasarkan data tersebut kualitas pelaksanaan pelaksanaan lesson study di SMKN 2 Seririt masuk kualifikasi sangat baik. Kualitas Pelaksanaan yang sangat baik tersebut memberikan efektivitas terhadap kompetensi profesional guru dan prestasi belajar siswa dengan kualifikasi tinggi. Hal ini menunjukkan bahwa secara deskriptif diklat lesson study efektif dalam meningkatkan kompetensi profesional guru dan prestasi belajar siswa.

Berdasarkan perhitungan paired samples test diperoleh angka statistik $t_{\text {hitungsama dengan 123,849 }>t_{\text {tabel }} 2,009}$ dan $p$ kurang dari 0,05 . Jadi hipotesis null $\left(\mathrm{H}_{\mathrm{o}}\right)$ ditolak dan dapat disimpulkan bahwa terdapat perbedaan yang signifikan prestasi belajar IPA siswa sebelum dan sesudah diklat lesson study. Rata-rata skor sesudah diklat lesson study $(80,593)$ lebih besar dibandingkan sebelum $(21,148)$ diklat lesson study. Korelasi antara prestasi belajar siswa antara skor sebelum diklat lesson study dengan skor sesudah diklat lesson study sangat tinggi, yakni 0,912 . Artinya, perubahan prestasi belajar siswa sebelum diklat lesson study berhubungan sangat erat dengan perubahan prestasi belajar siswa sesudah dilaksanaan diklat lesson study.

Secara umum kualitas pelaksanaan diklat lesson study di SMKN 2 Seririt masuk kualifikasi sangat baik dan ditinjau dari hasil pengujian hipotesis secara keseluruhan yang telah dijabarkan sebelumnya menunjukkan bahwa diklat lesson study terbukti memiliki pengaruh terhadap prestasi belajar siswa.

Keberhasilan pelaksanaan diklat lesson study ini disebabkan oleh: (1) kontribusi kepala sekola yang telah mendukung pelaksanaan diklat dengan mewajibkan guru IPA ikut diklat lesson study dengan memberikan surat formal. Selain itu, kepala sekolah memfasilitasi penggunaan alat sekolah untuk kegiatan tersebut seperti kamera, handycam, proyektor, dan perlengkapan lainnya serta ruangan baik ruangan kelas, perpustakaan, maupun ruang untuk pembekalan; (2) kontribusi guru dalam meluangkan waktu berpartisipasi dalam kegiatan diklat berbasis lesson study dan kesediaan mengikuti petunjuk teknis (Juknis) diklat; (3) kontribusi guru lain, wakasek, kepala sekolah, komite, BK, dan staf tata usaha sebagai observer undangan dalam kegiatan open class atau mendukung persiapan sarana prasarana; (4) ketersediaan sarana dan prasarana yang memadai untuk pelaksanaan lesson study; dan (5) kondisi sekolah yang kondusif di mana para guru bersedia berkolaborasi dan siswa bersifat kooperatif dalam PBM.

Setiap tahap pelaksanaan diklat berbasis lesson study guru memiliki kesempatan untuk mengembangkan dan meningkatkan kompetensi profesionalnya. Saat pembekalan para guru yang merupakan tim lesson study memperoleh pengetahuan dan pemahaman tentang lesson study, pengembangan bahan ajar, maupun cara pembuatan RPP. Kemudian kompetensi tersebut semakin diperkuat dalam proses implementasi lesson study sendiri yang terdiri atas 12 kali pertemuan di mana masing-masing pertemuan terdiri atas tiga tahap, yaitu plan, do, dan see.

Tahap plan (goal-setting and planning) meliputi kegiatan kolaboratif guru dalam melakukan: (1) indentifikasi tujuan pembelajaran; (2) membahas susunan, keluasan, dan kedalaman materi ajar; (3) pembuatan RPP; (4) pembuatan media pembelajaran; dan (5) simulasi PBM (Istamar dan Ibrohim, 2008). Pada tahap ini guru saling mengisi dan melengkapi baik dalam identifikasi tujuan pembelajaran, menentukan batasan materi yang akan diajarkan dan susunannya, pemilihan model pembelajaran, media pembelajaran yang akan digunakan, dan berbagi kata instruksional yang baik untuk digunakan. Tahap ini akan meningkatkan kompeteni profesional khususnya kemampuan guru dalam menguasai materi, struktur, konsep dan pola pikir keilmuan yang mendukung mata pelajaran yang IPA.

Dalam tahap do (research lesson) pengajar yang sudah ditunjuk dan 
disepakati untuk menjadi guru model melaksanakan tugas untuk melaksanakan pembelajaran yang sudah direncanakan bersama. Untuk guru model aspek kompetensi profesional yang dipengaruhi adalah konsistensi penguasaan materi guru antara content dengan performance. Dimana guru model dalam PBM berusaha menyampaikan pemahaman dan atau mengantarkan pemahaman siswa untuk menguasai materi secara utuh, terintegrasi, dan kontekstual dalam PBM misalnya dalam materi tsunami adanya ciri bau belerang sebelum terjadinya tsunami yang mirip dengan bau telur atau bau belerang di pemandian air panas. Selain itu, pada tahap ini guru model akan menemukan masalah, kesulitan, dan atau solusi misalnya dalam cara membangun konsep, pengelolaan kelas, pengalokasian waktu, penggunaan media, pengaturan kelompok, yang dapat digunakan refleksi diri untuk mengembangkan keprofesian. Sedangkan guru yang berperan sebagai observer, memantau proses pembelajaran yang terjadi utamanya pada kegiatan siswa. Selain itu, melalui pengisian format monitoring mereka juga memantau PBM yang dilaksanakan guru model sudah atau belum mencapai sasaran yang telah disepakati sebelumnya.

Pada tahap see (lesson discussion \& consolidation of learning) kelompok lesson study mendiskusikan dan menganalisis research lesson. Kegiatannya antara lain: (1) guru model mengemukakan masalah dan kesulitan yang dihadapi dalam pembelajaran; (2) para guru yang merencanakan pembelajaran menceritakan: alasannya dan menjelaskan perbedaan antara rencana; (b) apa yang telah dilaksanakan dan masalah/kekurangan dalam PBM berdasarkan lembar observasi siswa dan monitoring do; (c) miskonsepsi siswa; (d) solusi dan rancangan penyempurnaan PBM selanjutnya.

Hasil penelitian ini relevan dengan penelitian Sulasmi dan Rahayu (2006) menyatakan dari hasil monitoring dan evaluasi kegiatan piloting dan lesson study dalam pembelajaran biologi di sekolah menengah Kota Malang, Jawa Timur menunjukkan bahwa kegiatan ini dapat meningkatkan kualitas proses dan prestasi belajar biologi siswa. Peningkatan prestasi belajar siswa ini ditandai dengan peningkatan hasil belajar Biologi siswa, dari $72 \%$ siswa yang mendapatkan skor di atas 60 menjadi $97 \%$ siswa. Konsistensi hasil penelitian ini dengan penelitian sebelumnya menguatkan pembuktian tentang hipotesis penelitian ini secara empirik, bahwa terdapat pengaruh diklat lesson study terhadap prestasi belajar siswa.

Berdasarkan temuan dan hambatan dalam proses penelitian pengaruh diklat lesson study terhadap prestasi belajar siswa di SMKN 2 Seririt memiliki implikasi sebagai berikut. Pertama, setiap guru memiliki jadwal yang berbeda sehingga diperlukan komitmen dan penyusunan jadwal bersama atau sekolah mengatur jadwal agar ada waktu luang untuk guru mengadakan sehingga jadwal diklat lesson study tidak bersamaan dengan mengajar guru di kelas. Kedua, adanya perubahan pandangan belajar guru yang idealnya meliputi (melewati) empat hal yakni: (1) kolaborasi, artinya guru dapat bersama-sama merencanakan, melakukan PBM, merefleksi, dan menyempurnakan persiapan selanjutnya agar dihasilkan PBM yang lebih berkualitas. Di mana selama ini guru biasanya mempersiapkan dan melakukan PBM sendiri, jarang melakukan refleksi diri dan terkadang menyalin perencanaan milik guru lain; (2) refleksi, artinya guru harus siap diamati PBMnya oleh guru/pihak lain dan menerima kritik, saran, dan solusi dari hasil observasi tersebut. Selama ini kalau ada pengawas atau kepala sekolah yang ingin mengamati dan merefleksi kinerja guru, guru cenderung menghindar; (3) habituasi, artinya guru harus membiasakan diri terbuka menerima dan berbagi pengetahuan serta keahliannya dengan guru lain untuk pengembangan kompetensi berkelanjutan. Selama ini guru 
mengembangkan pengetahuannya dan keahliannya secara mandiri sehingga perkembangannya masih sangat terbatas misalnya masih banyak guru yang belum mahir menggunakan power point dan mengakses informasi dari internet sehingga tertinggal dari informasi kekinian; (4) kesadaran, guru menyadari bahasa intruksionalnya dan hal-hal yang dilakukannya di kelas melalui refleksi diri dan refleksi dari guru lainnya. Ketiga, pengembangan SDM di bidang pendidikan khususnya guru harus dilakukan secara berkala sehingga sesuai dengan tuntutan jaman.

Temuan ini konsisten dengan hasil penelitian yang dilakukan sebelumnya yaitu Anggara dan Umi (2012) yang menyatakan bahwa penerapan lesson study berbasis Musyawarah Guru Mata Pelajaran (MGMP) memberikan dampak positif terhadap peningkatan kompetensi profesional guru PKn SMP seKabupaten Ogan Ilir. Hal ini dikarenakan lesson study memberikan peluang kepada guru peserta lesson study untuk berdiskusi dan berlatih membuat perencanaan pembelajaran, menentukan media pembelajaran, menentukan metode pembelajaran, dan membuat kegiatan pembelajaran menjadi lebih efektif dan efisien.

Penelitian ini ini konsisten dengan hasil penelitian Sutriani (2010) dalam penelitiannya diperoleh peningkatan professionalitas guru dari open lesson 1 ke 2 sebesar $30 \%$ dan peningkatan dari open lesson 2 ke 3 sebesar 32\%. Peningkatan hasil belajar dari open lesson 1 ke 2 sebesar $7 \%$ dan peningkatan dari open lesson 1 ke 2 sebesar 18\%. Melalui implementasi lesson study professionalitas guru, aktivitas dan hasil belajar dapat meningkat; dan penelitiannya Sumarna (2006) menyatakan bahwa pelaksanaan lesson study berbasis sekolah membawa manfaat di antaranya: 1) Guru biologi menjadi termotivasi dan bangkit untuk membuat inovasi dalam pembelajarannya sehingga tercipta pembelajaran yang aktif, komunikatif, dan menyenangkan;
Selain itu, penelitin ini juga menguatkan hasil penelitianya I Wayan Sadia (2008) yang menemukan terjadi peningkatan kompetensi dan profesionalisme guru, meningkatankan kualitas proses dan hasil pembelajaran serta pengembangan pembelajaran yang demokratis berbasis paradigm konstruktivsme; dan hasil penelitiannya Ni Wayan Sukanadi (2010) menyatakan kualitas pelaksanaan lesson study. Pada guru SMA Negeri 1 Mengwi berkualifikasi sangat baik hasil belajar siswa sangat meningkat serta kompetensi pedagogi guru sesudah pelaksanaan lesson study lebih baik disbanding dengan sebelum pelaksanaan lesson study. Sekolah memiliki peranan penting dalam pengelolaan pengembangan SDM tentunya wakasek pengembangan SDM dengan cara mengaktifkan kelompok MGMP masing-masing mata pelajaran di sekolah salah satu alternatifnya adalah melaksanakan lesson study secara bergilir setiap semester.

Berdasarkan hal tersebut implikasinya bagi manajemen sekolah adalah merancang lingkungan belajar sedemikian rupa agar guru dan siswa mampu menerapkan berbagai model pembelajaran kooperatif terutama kesiapan sarana dan prasarana belajar seperti perpustakaan, internet, dan kelas dengan proyektor harus tersedia secara memadai untuk memenuhi kebutuhan guru dan siswa dalam mencari dan menggali berbagai informasi selama proses pembelajaran berlangsung.

\section{SIMPULAN DAN SARAN}

Berdasarkan hasil penelitian dan pembahasan maka dapat disimpulkan beberapa hal sebagai berikut. (1) kualitas pelaksanaan diklat lesson study pada guru IPA di SMK Negeri 2 Seririt masuk kualifikasi sangat baik $(\bar{X}=$ $91,781)$;dan (2) terdapat perbedaan prestasi belajar IPA siswa sebelum dan sesudah diklat lesson study $(\mathrm{t}=123,8493 ; \mathrm{p}<0,05)$. Rata-rata skor sesudah diklat lesson study $(80,593)$ lebih besar dibandingkan sebelum $(21,148)$ diklat lesson study. 
Berdasarkan berbagai temuan pada penelitian maka dapat disarankan beberapa hal, yaitu sebagai berikut. Pertama, bagi Dinas Pendidikan apabila akan melaksanakan diklat lesson study hendaknya memperhatikan: (a) kesediaan, kesiapan, motivasi, dan keluangan jadwal guru untuk melaksanakan diklat lesson study; (b) kesiapan sarana prasarana sekolah dan dukungan kepala sekolah; dan (c) penghargaan berupa honor, sertifikat, dan atau kredit poin agar guru termotivasi untuk mengikuti diklat lesson study. Solusi pelaksanaan diklat dapat dilaksanakan antarsekolah dengan jadwal bergilir sesuai keluangan jadwal mengajar guru.

Kedua, bagi kepala sekolah yang hendaknya mendorong bidang pengembangan SDM untuk aktif melaksanakan kegiatan diklat lesson study berbasis sekolah secara bergilir untuk masing-masing per kelompok guru mata pelajaran di sekolah guna peningkatan kualitas guru hendaknya memberikan keluangan/pertukaran jadwal bagi guru saat mengikuti diklat lesson study supaya saat pelaksanaan diklat guru tidak berbenturan dengan jadwal mengajarnya.

Ketiga, untuk kelompok guru yang akan melaksanakan diklat lesson study permalasahan yang sering ditemui adalah masalah teknis dan masalah persepsi negatif guru tentang diklat lesson study beberapa kiat yang penulis sarankan untuk meminimalisir munculnya permasalahan tersebut adalah: a) membuat JUKNIS; b) membuat surat penugasan untuk semua anggota tim lesson study; c) sesudah diberikan surat penugasan, masingmasing anggota tim lesson study diminta menandatangani surat penyataan bersedia mengikuti diklat lesson study dengan sebaik-baiknya; d) melakukan pendekatan secara pribadi; e) menginformasikan satu hari sebelum dilaksanakan pertemuan lesson study secara langsung, melalui telpon, atau SMS; dan f) menambah tata tertib kehadiran pada juknis lesson studi dengan tujuan keseluruhan penyampaiannya dalam PBM diikuti semua anggota.

Sebelum pelaksanaan lesson study: (a) guru harus diberitahukan secara detail aturan-aturan pelaksanaan lesson study; (b) siswa diberitahukan akan diadakan lesson study dan persiapan yang harus mereka lakukan misalnya wajib membawa nomor punggung sesuai nomor absen yang berisi nama lengkap dan pembentukan kelompok kecil; (c) Mengatur ruangan kelas sesuai kebutuhan, misalnya untuk di SMK Negeri 2 diberikan jarak antara bangku dengan tembok dibagian belakang dan pinggir dekat pintu keluar untuk mempermudah ruang gerak observer dan apabila ada observer yang permisi untuk buang air kecil tidak melalui bagian tengah sehingga tidak mengganggu fokus siswa. Serta, dalam tahap refleksi: (a) fokuskan komentar pada kegiatan siswa dan apabila ada komentar untuk guru hanya boleh menyampaikan komentar positif, hindari penyampaian komentar negatif untuk menghindari ketersinggungan guru model; (b) gunakan "pembelajaran kita/kelas kita" untuk mengomentari PBM agar semua tim merasa bertanggung jawab dan memiliki PBM tersebut tidak hanya guru model.

Keempat, untuk peneliti selanjutnya dapat memperluas penelitian diklat lesson study dengan alternatif metode misalnya penelitian tindakan kelas, pengembangan, one shot case study, metode kombinasi model concurent embed. Dapat juga dengan meneliti variabel terikat lainnya misalnya kemampuan pengelolaan kelas, kinerja guru, kemampuan mempersiapkan pembelajaran, dan lain sebagainya. Selain itu, mengembangkan variabel yang berkaitan dengan siswa misalnya karakter, kemampuan pemecahan masalah, kemampuan psikomotor, dan afektif siswa.

\section{DAFTAR PUSTAKA}

Agusyana, Y. (2011). "Olah Data Skripsi dan Penelitian dengan SPSS 23." Jakarta: PT. Gramedia. 
Anggara, R., \& Chotimah, U. (2012). Penerapan Lesson Study Berbasis Musyawarah Guru Mata Pelajaran (MGMP) terhadap Peningkatan Kompetensi Profesional Guru PKn SMP Se-Kabupaten Ogan Ilir. Jurnal Forum Sosial, 5(2), 188197. Retrieved from http://eprints.unsri.ac.id/1421/\%5C nhttp://eprints.unsri.ac.id/1421/1/P enerapan_Lesson_Study_berbasis _MGMP_PKn.pdf

Astuti, R., Sunarno, W., \& Sudarisman, S. (2012). Pembelajaran IPA Dengan Pendekatan Keterampilan Proses Sains Menggunakan Metode Eksperimen Bebas Termodifikasi Dan Eksperimen Terbimbing Ditinjau Dari Sikap IImiah Dan Motivasi Belajar Siswa. Universitas Sebelas Maret. Retrieved from http://jurnal.pasca.uns.ac.id

Burghes, D., \& Robinson, D. (2009). Lesson Study: Enhancing Mathematics Teaching and Learning. University of Plymouth. Retrieved from http://www.cimt.plymouth.ac.uk/pa pers/lessonstudy.pdf

Bustami. (2009). Pengaruh pengembangan profesionalisme guru smp terhadap peningkatan mutu pendidikan di kabupaten aceh timur. Universitas SumatraUtara.

Candiasa, I. M. (2010). Statistic Univariat dan Bivariat Disertai Aplikasi SPSS. Singaraja: Unit Penerbitan UNDIKSHA.

Febrina, Y. (2012). Pengaruh Kompetensi Pedagogik Guru Ekonomi Terhadap Hasil Belajar Siswa 1 Tambang Kabupaten Kampar. Universitas Riau.

Hendayana, S. dkk. (2006). Lesson Study Suatu Strategi Untuk Meningkatkan Keprofesionalan Pendidikan Pengalaman IMSTEP. Bandung: UPI Press.

Istamar, S. dan I. (2008). Lesson study Studi Pembelajaran Model
Pembinaan Pendididik dipetik dari Pengalaman Implementasi Lesson study dalam Program SISTTEMS JICA di Kabupaten Pasuruan. FMIPA UM.

Kemendikbud. (2012a). Grafik Hasil Uji Kompetensi Guru.

Kemendikbud. (2012b). Pedoman Uji Kompetensi Guru. Jakarta: Kemendikbud BPSDMPK-PMP.

Lewis, C. dkk. (2006). How Should Research Contribute to Instructional Improvement The Case of Lesson study. Educational Researcher, 35(3), 3-14.

Masitoh, U. (2013). Peningkatan Hasil Belajar Siswa Menggunakan Pembelajaran Dd Ct Dengan Media Power Point Pada Materi Bumi Dan Benda Langit Siswakelas $X$ Program Keahlian Tata Busana 2 Smk N 4 Surakarta Tahun Ajaran $2012 \quad 2013 . \quad$ Universitas Muhamadyah Surakarta.

Renes, I. W. (2009). Identifikasi FaktorFaktor Kendala Ketidaklulusan Sertifikasi Guru Smk di Kabupaten Gianyar Tahun 2007. Universitas Pendidikan Ganesha.

Sugiyono. (2012). Statistika Untuk Penelitian. Bandung: Alfabeta, cv.

Sugiyono. (2013). Metode Penelitian Kombinasi (Mixed Methods). Alfabeta. Bandung: Alfabeta, cv. https://doi.org/10.1016/S09694765(04)00066-9

Sukanadi, N. W. (2010). Lesson study Sebagai

Strategi

UntukMeningkatkan Kompetensi Pedagogic Guru IPA dan Dampaknya Terhadap Hasil BelajarSiswa Di SMA Negeri 1 Mengwi. Universitas Pendidikan Ganesha.

Sulasmi, E.S., dan Rahayu, S. (n.d.). Hasil Monitoring dan Evaluasi Kegiatan Piloting dan Lesson study dalam Pembelajaran Biologi di Sekolah Menengah Kota Malang. In Prosiding Seminar Nasional Penelitian, Pendidikan, dan 
Penerapan MIPA,. Yoyakarta.

Sumarna. (2006). Implementasi Lesson study Sekolah untuk MeningkatkanKemampuan Guru Biologi Melakukan Pembelajaran Inovatif. In Seminar Nasional MIPA 2006. Retrieved from http://eprints.uny.ac.id/id/eprint/11 946

Susilo, H. (2013). Lesson Study Sebagai Sarana Meningkatkan Kompetensi Pendidik. In Seminar dan Lokakarya PLEASE 2013. Lawang. Retrieved from http://sttaletheia.ac.id/wpcontent/uploads/2013/07/LessonStudy-Sebagai-SaranaMeningkatkan-KompetensiPendidik-herawati.pdf

Susilo, H. dkk. (2011). Lesson Study
Sekolah Guru Konservatif Menuju Guru Inovatif. Jatim: Bayu Pubshing.

Sutriani. (2010). Peningkatan Profesionalitas Guru Melalui Implementasi Lesson Study. Universitas Negeri Semarang.

Wayan, S. I. (2008). Lesson Study. (Siiatii Strategi Peningkatan Profesioalisme Guru). Jurnal Pendidikan Dan Pengajaran Undiksha. 